\title{
An exploration of the lineage of female utopian literature
}

\begin{abstract}
My paper assesses the effects of periodization on feminist representations of utopias. The first text acknowledged is Margaret Cavendish's The Blazing World, followed by Charlotte Perkins Gilman's Herland, and concluding with Angela Carter's collection of short stories entitled The Bloody Chamber. The paper demonstrates how one can mark the different movements within feminism throughout history as the nature of the utopian genre is that it reflects the desires of individuals within contemporary society. The utopia as a genre is becoming an increasingly diverse literary segment and one which can be described as under construction. We are moving towards new terms such as 'ustopia' which acknowledges that one's utopia can be another's dystopia. The utopian genre fuels and supports critical and satirical writing and so the method of periodization and assessing its lineage leads to illuminating details on historical movements which in this case is feminism.
\end{abstract}

Key words: feminism, utopmia, periodization, dystopia, gender politics.

\section{Introduction}

Female writers tend to turn to the utopian or science fiction genre due to the freedom it affords them from the constrictions of realism which enables them to envisage a world wholly of their own design. The subversive nature of the genre allows writers to critique and hold a mirror up to society, exposing its flaws and injustices by writing of a world they desire. The term 'utopia' was coined by Sir Thomas More in his novel Utopia, published in 1516. The word derives from the Greek term ou-topos meaning 'no place', punning on the similar Greek term 'eu-topos' meaning 'a good place.' A utopia is the presentation of an ideal society which often satirizes aspects of both the idealized society that the text portrays and indirectly, the society known to the author and intended reader. The function of a utopia is to incite "speculation, offer alternative vicarious experience, spur us as readers to re-evaluate and act upon our own world" (Kessler 1995: xvii). This paper will explore the changing presentation of female utopias in connection with the gender politics and social context of each work and how they each mark or pre-empt different movements of feminism. 'Utopias and science fiction by women - women's 'literature's of estrangement' - constitute a continuous literary tradition in the west from the seventeenth century until the present day"

1 Address for correspondence: 22 Sanderling Close, Bicester, Oxon, OX26 6WF, United Kingdom. E-mail: emmacrabtree@msn.com 
(Donawerth \& Kolmerten 1994: 1). Therefore, the first text to consider is Margaret Cavendish's The Blazing World first published in 1666, after the Restoration of the Stuart monarchy, in a period when gender roles and female sexuality were extremely rigid. The work presents the reader with a fantastical utopia exploring natural science, philosophy, and astrology through the powerful and dominant Empress. Cavendish's bold and pioneering text engages with topics and a literary genre which was seen as strictly masculine. Francis Bacon's utopia New Atlantis (1627) can partially be seen as a foundation which Cavendish aims to write against by pushing women and female perspectives into these male spheres. The same applies to the second text to be considered. Charlotte Perkins Gilman's Herland was written in 1915 at a time when the first movements of feminism were emerging in America and parts of Europe. At this time gender roles were slowly changing causing many discrepancies between notions of tradition and progression. In an almost opposite portrayal of a female utopia to Cavendish's, Gilman writes of an entirely female society in which motherhood is seen as the epitome of womanhood. Three men explore and attempt to be socialised into this world and interestingly the feminist story is unexpectedly focalized through the male perspective. In 1912 Arthur Conan Doyle had published The Lost World, which follows a similar premise in that it depicts a discovery and exploration of a forgotten land also peopled by fantastic creatures. His novel is an example of a classic masculinity fantasy of imperial conquest and domination of virgin territory.

Both Cavendish and Gilman feminize utopian fiction and push against the male creations within this genre. Contrastingly, Angela Carter's collection of fairy-tales, The Bloody Chamber (1979), has its roots in the feminine as the European fairy-tale traditionally figures the woman as the storyteller. However it is a literary tradition which male writers such as Brothers Grimm and Andrew Lang tried to mark as their own in the eighteenth and nineteenth centuries through their collection, publication, and commercialisation of fairy-tales. Writing at the time of the second wave of feminism, she adopts and revitalizes an archaic feminine genre to enforce her feminist message. The fairy-tale enables Carter to have an unrestricted setting for her tales, allowing her to re-write traditional gender roles. She sexualises her females, they desire men, take control and can be violent. This is an alternative type of utopia to the previous texts. A utopia is a subjective creation as each person has a different view on what a utopia should entail. The utopia as a genre is becoming an increasingly diverse literary segment and one which can be described as 'under construction'. The term 'gynotopia' is increasingly applied to a fictive world rid of males such as Herland which also depicts both utopian and dystopian features. Similarly, Margaret Atwood created the term 'ustopia' "by combining utopia and dystopia - the imagined perfect society and its opposite - because in [her] view, each contains a latent version of each other" (Atwood 2011 online). Given the historical context of each of these texts and the individual feminist ideas which each author held, there are dystopian aspects to each work. Nevertheless, it is important to consider the texts within the time in which they were created and to consider how the authors and their publications contribute to or pre-empt the different movements of feminism. Female utopias depict "how women are profoundly alienated and limited by patriarchal society; they then go on 
to acquaint the reader with an alternative society in which women could feel at home and manifest their potential" (Pearson 1977: 50). This potential is expressed in the specific areas of female liberation such as: education, motherhood and the removal of patriarchal ideals, and embraced female sexuality.

\section{Margaret Cavendish, female rule and education}

The Blazing World opens with a note to the reader which sets up the authoritative female voice governing the rest of the novel:

For I am not covetous, but as ambitious as ever any of my sex was, is, or can be; which makes, that though I cannot be Henry the Fifth, or Charles the Second, yet I endeavour to be Margaret the First. (124)

To be a woman in the seventeenth century however was to be domestic, obedient, and silent. A woman's place was not in discussing the current debates within the sciences and philosophy. Fortunately, Cavendish was not an ordinary seventeenth-century woman. She was flamboyant, bold, and ambitious as shown through the various frontispieces to her works. The Blazing World was published alongside Observations upon Experimental Philosophy, her theories about natural science. This combination is highly evocative of New Atlantis, which was published with Sylva Sylvarum, Bacon's text on natural history. While Marina Leslie (1996: 9) states that Cavendish is "clearly imitating Bacon", I would argue that she is not so much 'imitating' but forcing herself into a male domain through publishing two different texts. Cavendish reacts against the notion that women must only discuss matters within the domestic sphere. To publish both a fantastical fiction and a thoughtful exploration of natural science, adds more validation to Cavendish's project than fiction alone.

Cavendish was a force to be reckoned with. She became the first woman to attend a meeting at the Royal Society of London in 1667. Here she openly engaged with and critiqued the other members including Thomas Hobbes and René Descartes. A place where women could learn and join discussion was her utopian ideal. The Empress in the text therefore establishes a scientific academy where she can grapple with her questions about natural science with other members of the Blazing World. This creation "resembles and critiques both the Royal Society [...] and its utopian inspiration, Salomon's House in Bacon's New Atlantis, an academy of male Elders" (Trubowitz 1992: 234-5). While Bacon portrays an academy of males which is evocative of the society in which he lived in, Cavendish promotes sisterhood in her novel. The Empress recognised that women were excluded from parts of religion in the Blazing World and so she endeavoured to convert them to her religion. In this section Cavendish not only promotes the feminist ideal of sisterhood, but also manages to fight against female stereotypes. The women are described as having "quick wits, subtle conceptions, clear understandings, and solid judgements" (162). This unity of women is reiterated when the Empress befriends the equally independent and empowered 
Duchess, and both women are nearly inseparable. Throughout the novel, the Empress's power is shown to be natural and innate, and the prefatory note to the reader adds: "I have made a world of my own: for which no body, I hope, will blame me, since it is in every one's power to do the like" (124). This allows the reader to see that they too hold power. While Cavendish encourages sisterhood and empowerment, one cannot ignore the domineering matriarchal figure of the Empress who is given "absolute power to rule and govern all the world" (132). Cavendish was a devout Royalist throughout the turbulent seventeenth-century. It is therefore unsurprising that unlike Gilman's text where all the women are equal in status, Cavendish chooses the "figure of absolute sovereign [...] as a monarchical ideal of the independent woman" (Trubowitz 1992: 231). By instating a monarch, Cavendish "aligns the [utopian] form with her aristocratic nostalgia for what could be called a 'magical' past, for an idealized pre-Civil War England" (Trubowitz 1992: 231). Some may read this figure who holds absolute power as a rather dystopian character especially in the seventeenth century. However, the reminder from Cavendish that the world is of her own creation, gives the sense that the Empress can be an 'everywoman' figure of anyone's creation.

While Gilman emphasises the value of motherhood, Cavendish distances her Empress from the familial role and uses the Duchess to critique the restrictions on women. Cavendish allows one sentence to address the fact that the Empress had children: "nor durst anyone wear jewels but the Emperor, the Empress, and their eldest son" (133). To focus on the Empress adopting the role of the mother and wife would not be Utopian, in Cavendish's interpretation of the concept. The presentation to the reader that the Empress is simultaneously a mother, a ruler and engaged in current intellectual debates demonstrates Cavendish's view that there is more to women than domesticities. The voice of Cavendish is focalised through the Duchess who states: "I had rather die in the adventure of noble achievements, than live in obscure and sluggish security" (185). This powerful statement directly attacks the ideals of patriarchy which suffocated women in the seventeenth-century, who were forced to live in "sluggish security" leaving them "buried in oblivion" (185). In many respects, Cavendish writes against the male utopias of the time. Her utopia is set up as a direct opponent to these male creations, a work to be considered as wholly separate in what it represents. However, "she also seeks inclusion in male literary and philosophical canons" (Leslie 1996: 7) by demonstrating both in her life and her work that women deserve a place within them. Her utopia "challenges seventeenth-century concepts of identity and gender" (Pohl 2003: 51). Cavendish's proto-feminist stance led her to gain the reputation of the "crazy Duchess" (Woolf 1996: 57-8).

\section{Charlotte Perkins Gilman and her Edenic fantasy}

It is striking that after a distancing of the female from the domestic with Cavendish, that Gilman's utopia would draw the two closer together in Herland. In 1915, Gilman is writing during the first wave of feminism and the First World War which both challenged gender roles. There are aspects of the novel which are problematic for the modern-day reader which now places Herland within Atwood's category of the 'ustopia'. Nevertheless, considered in its historical context these 
issues cannot cloud the powerful and still relevant feminist messages which Gilman's utopia offers. Three years prior to publishing Herland, Conan Doyle's The Lost World was published, and it could be said that Gilman used his text as a platform to give a gynocentric perspective of the exploration of a previously undiscovered land for her feminist utopia. "Choosing a utopian vehicle, five years before the passage of women's right to vote she produced [...a] rare classic Edenic fantasy" (Snodgrass 2006: 261-2).

Gilman instantly reverses the traditional gender roles of society in Herland with males being inferior. The presentation of three distinctly different but stereotypical men is more evocative of male culture than if there were only one male in the novel. The focalisation of the female utopia through the male gaze and voice was an unexpected feature, but as the novel develops it is beneficial to Gilman's message. It creates a larger impact as the male voice suddenly aligns itself with the thoughts of the female reader. The strength of the patriarchal views held by men is evident as Terry not only sexualised the women with his "visions of a sort of sublimated summer resort" which "he had pleasant dreams" about (9). He also assumed that he would be "elected King in no time" (11) as from his chauvinist and unreflective perspective, a land is not functional without male dominance. The benefit of having Van as the narrator means that he acts almost as a mediator. He criticises Terry for his views and gives the reader the presentation of an empathetic male ally: "as I learned more and more to appreciate what these women had accomplished, the less proud I [became] of what we, with all our manhood, had done" (79).

Gilman removes the patriarchal expectations on women, and so their appearance is entirely based on practicality as they "dress to suit health and comfort" (Snodgrass 2006: 53). The men are baffled by the lack of vanity which they perceived as a feminine trait but realise is a product of the patriarchy. In the same way Van is enlightened when he finds intelligent and dependable women as these were supposedly masculine traits. Gilman revels in making the three men experience what women in the real-world were constantly experiencing. In chapter two, Van describes that they "were much in the position of the Suffragette trying to get to the Parliament buildings" (30). During their imprisonment Jeff notes that "they've given us a room - with no great possibility of escape - and personal liberty - heavily chaperoned" (38). For a female reader at this time this confined environment may have been rather familiar and is wittily evocative of the life of a married woman. The men realise that the women "needed neither protection nor service. ... [they] were their guests, their prisoners, absolutely dependent" (119). For women, this was life in a patriarchal society. For the male reader this novel is designed to force them to reflect on the natural justice of the first phase of the feminist movement.

Georgia Johnston notes that "Gilman shows how the men, in a way, go back to the mother's womb, in which they, like children, learn a new language, new customs, a new history" (Johnston 1991: 58-9). They enter a land which is feminised in its description, which problematically reiterates the supposed domestic nature of women: "everything was beauty, order, perfect cleanness, and the pleasantest sense of home over it all" (25). Aside from this, it is a land where "every woman values her maternity above everything else" (110). Motherhood is their religion, and so the men 
are engulfed in a wholly female space driven by maternity. In some way, the men do re-enter the womb and this perhaps shows Gilman's desire for society to be re-born without its prejudices. This emphasis on motherhood is interesting as Gilman was writing when Marie Stopes embarked on her research into methods of contraception which changed the cultural approach to motherhood and female sexuality. The presentation of a sisterhood provides "a source of validation and spiritual nourishment and [is] a crucial element of female liberation" (Snodgrass 2006: 493). It empowers women and encourage unification over Cavendish's empowered individual, although in Gilman there is the loss of the individual which is also problematic.

It is challenging as a modern-day reader to find the feminist message in the absolute emphasis on motherhood and the retreat from female sexuality. For motherhood to be the entire focus of the Herlander's lives is an interesting position given the lives of women in the real world. When Gilman glorifies “female 'instincts' of love and service, her radical theory of feminism dissolved into a sometimes-sentimental worship of the status quo" (Hill 1980: 525). However, these ideas fit in with "a turn-of-the-century feminist perspective" (Miller 1983: 192-3) which came under the name of the 'Social Purity Movement' of which Gilman was a supporter. "The movement was driven by concepts of celibacy [...] abstaining from sex was a wholly feminist cause" (Kent 2018 online). Followers of this movement believed that abstinence was the only way to gain equality. Francis Swiney stated that sexual "desire was 'not natural' and was likely part of the unnatural patriarchy. [...] For Swiney, women were destined to lead the human race to an egalitarian and asexual state" (Kent 2018 online). This is a concept which in the light of Herland is rather familiar where "there was no sex-feeling to appeal to" (122). The feminist movement thought that instead of relieving women of the patriarchal expectations, they would raise men to be as pure as women. When considering Gilman's work in the period in which it was written, it is absolutely deserving of its status as a utopian feminist landmark as it skilfully reverses the gender roles to critique the society at the fin-de-siècle. However, from a modern-day perspective it is perhaps less deserving of this status.

\section{Angela Carter and sexual liberation}

In 2015, Lindy West wrote a new introduction to Herland and concluded: "my twenty-first-century Herland would be, I'd hope, a little less perfect than Gilman's original - because women are people" (West 2015: xiii). The third text to be considered fulfils this idea of an imperfect world where women are returned to their natural and in some cases deeply flawed selves. For Carter, allowing women to be true and imperfect was a utopian ideal. She fights against the social restraints on women which force them to become unnatural. The collection is a "catalyst of a million awakenings for readers (especially girls)" (Warner 2013 online). The reinstatement of eroticism into what is seen as a genre for children, was a shocking decision by Carter. Through the subversion of gender roles, the stories powerfully reveal how fairy-tales participate "in constructing the boundaries of masculinity and femininity by reinforcing traditional ideas about sex roles” (Seago 1999: 84). 
“The Tiger's Bride" instantly confronts the reader with the reality that women were viewed as mere possessions as it opens with: "My father lost me to The Beast at cards" (51). The heroine in the story is coming of age, as are the majority of Carter's heroines, and therefore she is virginal which makes her more valuable. The girl finds affinity with the Beast as she realises that like the Beast with his mask, she is also an imitation of a human. The story is littered with references to her past where women would try to "scare [her] into good behaviour, for [she] was a wild wee thing" (56). She later adds: "I let out a raucous guffaw; no young lady laughs like that! [...] But I did. And do" (58). As she removes her clothes she removes social restrictions. Through her sexual exploration with the Beast she becomes her natural self: "each stroke of his tongue ripped of skin after successive skin, [...] and left behind a nascent patina of shining hairs" (67). Similarly in the wolfstories, the girls are shown as virginal but not overly naïve. Instead they display a natural curiosity about sex. The imagery within the stories is often of blood which is simultaneously connected to animalism, menstruation and the loss of virginity. In Carter's collection, blood becomes a symbol of embraced woman hood and empowerment. The 'strong-minded' heroine in "The Company of Wolves" wears a red shawl which had the "brilliant look of blood on snow" (113). Further into this description it is revealed that "she has just started her woman's bleeding" (113). Armed with a knife and her womanhood, she refuses to submit to the wolf. The story concludes with her laughing in his face knowing that "she was nobody's meat" (118).

Carter empowers her heroines by depicting them as in control with the ability to make wolves 'tender' and yet she simultaneously aligns the girls with wolfishness. The unapologetic presentation of what is bestial in women is refreshing and puts her women in a new light in which "portray an ambiguous mixture where good and evil depend on perspective, denying the reader the reassuring certainty of approval and identification" (Seago 1999: 94). Carter's females are human with desires and imperfections, she had "no interest in presenting a one-dimensional view of women" (Haase 2000: 22). In stories such as "The Bloody Chamber", the heroine describes her mother with "her skirts tucked round her waist, one hand on the reins of the rearing horse while the other clasped [her] father's service revolver" (40). Not only do Carter's women save themselves, but the strong mother-figures often missing from traditional fairy-tales are heroes. However, Carter is careful when depicting women truthfully and this is why a presentation of the perfect sisterhood is not seen in her collection. In other stories such as "The Snow Child" and "The Werewolf", women can cause each other's destruction. In "The Werewolf” the wolf is the grandmother. Not only does Carter sexualise her young women, but as seen with the above description of the mother from "The Bloody Chamber" and with the grandmother from "The Company of Wolves", she sexualises the older women as well. It is shocking for the reader to read a salacious passage of the grandmother being approached by the wolf: "His genitals, huge. Ah! Huge. The last thing the old lady saw in all this world was a young man, [...] naked as stone, approaching her bed" (116). The uncomfortable nature of a passage like this forces the reader to acknowledge how society has taught us to view women of an older age as non-sexual beings. 
Carter's writing in this collection is steeped in the feminine. As previously stated, the form of the fairy-tale is in itself inherently female. "Storytelling is 'semiotically a female art' [...] by pointing not only to women's traditional role as storytellers but also to the ways in which they have been represented as the spinners of tales in folklore" (Haase 2000: 29). The oral/aural origins of fairy-tales mean that unlike the other texts, there is no concrete male platform. It is key to note two other features of the fairy-tale genre. Firstly, due to the nature of how fairy-tales were told, they naturally adapt to the "socio-cultural context at each moment of mediation" (Seago 1999: 86). So, for Carter to write out patriarchal views from the classic tales during second wave feminism is a stage of natural progression for the genre. Secondly, Carter removes the usual omniscient, third-person narrator in some of her stories to use a first-person narrator to liberate the previously suppressed female voice. Although Carter's feminism is rather controversial, she demonstrates that the best an author can do is to depict the reality of being a woman. Instead of being a 'perfect' place, Carter's utopia is where people are themselves and this is a combination of the good and the bad which aligns itself with the concept of 'ustopia'.

\section{The evolution of gender politics and female utopias}

Although the three texts are part of the same literary genre and part of the feminist movement as a whole, they are distinctly different in the messages which they put across. This is largely due to the eras in which they were written. Nevertheless the critical and satirical nature of utopian fiction provided these female writers with a free space to critique the gender politics of their time. Each of the authors' adaption of an established male literary platform adds to their feminist messages and brings the female perspective and voice into the forefront of a male-dominated art form. By reflecting on the progression of this genre which criticises contemporary social issues, one is able to mark the evolution of political views. Or perhaps something more like culturally-conditioned obsessions - whereby the seventeenth century text seems preoccupied with female education, the early twentieth-century text with motherhood, and the late twentieth century text with sexuality. Ultimately these texts enable us to mark key sentiments and developments within the feminist movement. The benefit of using the utopian or science fiction genre is "that gender roles can be more easily revised when the reader is estranged from her ordinary world" (Donawerth \& Kolmerten 1994: 2). As established throughout this article, the utopian genre is diverse and is still somewhat establishing itself as it gains new terms for possible sub-genres or new names for the genre itself (ustopia, gynotopia, etc.). Utopian fiction allows its authors to depict a land which is their personal idea of paradise. This element of subjectivity contributes to the emerging terms which are now being applied to these 'utopias'. There is no blueprint for an ideal world as naturally we all have different notions of paradise and perhaps for this reason the notion of a utopia is inevitably flawed. Some argue for the creation of a 'protopia' over a utopia which does not seek perfection but for the depiction of a society with improvements. Again, one person's improvement to society will be seen by another person as a negative step leading to the deterioration of a society. As our society becomes more self-aware of its prejudices and conscious of political correctness, 
we may almost entirely abandon the notion of a utopia as we realise human nature does not go in hand with perfectibility. I believe that Atwood's term 'ustopia' is the most suitable term to adopt for utopian works.

The act of compiling research for this article required one to adopt the new historicist approach when analysing a line of descent, connectedness or thematic or intertextual linkage. New historicists place literary texts within their historical context in order to gain a deeper understanding of the work and the author's motivations for writing. They also force us to acknowledge that our access to the 'reality' of the past is itself conditioned textually, and in part constituted by our reading of fiction. Not only does new historicism give a broader understanding of the individual texts, but as demonstrated it enables us to connect multiple texts to multiple eras and identify connections and patterns. For example, each of the three works discussed, successfully mark the progression of the feminist movement through the critical and satirical nature of the utopian genre itself. Acknowledging the pattern/line of descent of the genre allows us to map the progression and possible future of the genre.

Similarly to the new historicist approach to literature, the act of periodization provides us with a framework to help us segment and understand the progression of cultural and political attitudes throughout history. A problem which arises with periodization is that the historical, political and social periods or categories into which we separate time are not so rigid in reality. Throughout history, cultural and political beliefs change and evolve over a stretch of time. It is not a sudden change from one period to another which is often how periodization presents history. The following quote is a comment on periodization by Jeanette Winterson, voiced through her character Sappho in her fiction Art and Lies: "All art belongs to the same period. The Grecian drinking horn sits beside Picasso's bulls, Giotto is a friend of Cezanne. Who calls whom? Sappho to Mrs Woolf - Mrs Woolf to Sappho. The Over-and-Out across time, the two-way radio on a secret frequency. Art defeats Time" (Winterson 1995: 67).

This is a key example of where Liberal Humanism (as perfectly captured by Winterson) conflicts with New Historicism: Art is seeking some kind of ideal form and immortality which History presses down on it and tries to enfold and limit it within a series of time capsules. Utopias are fascinating because their creation by writers in different eras are almost an admission that History is winning, as seen in these disparate creations of alternative realities where conditions for women are otherwise. The changes and developments within art are indicative of the changes within society as demonstrated through the historicist and feminist analysis of the texts of Cavendish, Gilman and Carter.

Periodization can be easily applied to specific movements within history. For example, in her own periodization of feminist literary history, Elaine Showalter identifies three phases of feminism and feminist literary theory. The Feminine Phase starts in 1840 until 1880 and in this period female writers imitated dominant male literary and artistic forms. This was followed by the Feminist Phase from 1880 until 1920 where female writers presented more radical positions. Showalter concludes with the Female Phase from 1920 onwards which encompasses a close analysis of the experiences 
of women and their writing. These three phases allude to the issues of periodization as Showalter's divisions can be contradicted namely by the work of the female writers who make up the article. As this paper shows, in 1666 Margaret Cavendish was using dominant male forms to push her feminist ideals and desires into the public and male sphere. However, the term 'feminism' and the notion of what it stood for was non-existent in the seventeenth century. Therefore, Cavendish is proto-feminist and as such this means that she can be somewhat excluded from an analysis of the progression of literary feminism. Periodization often causes researchers and critics to look at the past and label people and works within it with modern terminology which may be argued as an incorrect action. Also, it must be acknowledged that for any labelled part of history, there will always be outliers and works to contradict the time setting as time and human nature are more fluid than periodization allows for. Nevertheless, Showalter's 'feminine phase' seems rather limiting as in the time after 1880, as I have demonstrated, female writers were continuing to use the male literary forms as platforms to their works. This was simultaneously through the imitation of the genre the subversion of its traditions. Her allusion to the radical feminist phase in the late nineteenth and early twentieth centuries offers another point of discrepancy. It is true that this was the time when feminism was emerging and was being acknowledged as a belief or movement. However, I argue that throughout each of the three eras and the texts I have written on, each author has put forward radical ideas both before, during and after the historical period Showalter outlines. Meanwhile, the third phase refers more to literary criticism than to female literature itself.

In conclusion, the act of periodization in many cases is a key way to provide order and a framework to our existence which without this structure would be near impossible to work with. Regardless of outliers and the blurred edges of the time periods and their associated ideologies and aesthetics, overall periodization enables us to chart developments within history as seen with the feminist movement and the utopian texts of the three female writers. Each text aptly marks key moments in the process of giving women a voice and a place within society. This correlation is made clear through the act of periodization and the utopian genre which was created for the purpose of critiquing and satirising society.

\section{References}

\section{Primary sources}

Carter, A. 1995. The Bloody Chamber. London: Vintage.

Cavendish, M. 2004. The Blazing World and Other Writings, ed. Kate Lilley. London: Penguin Books.

Gilman, C. P. 2015. Herland. London: Vintage Classics.

\section{Secondary sources}

Anon. Utopia, The British Library, http://www.bl.uk/learning/histcitizen/21cc/utopia/utopia.htm>, [Date Accessed: 12/11/2018] 
Atwood, M. 2011. Margaret Atwood: The road to ustopia. The Guardian. https: / / www.theguardian.com/books / 2011 / oct / 14 / margaret-atwood-road-to-ustopia (22 October 2018).

Donawerth, J. \& Kolmerten, C. A. 1994. Utopian and Science Fiction by Women: Worlds of Difference. New York: Syracuse University Press.

Haase, D. 2000. Feminist fairy-tale scholarship: A critical survey and bibliography. Marvels and Tales 14: 15-63.

Hill, M. A. 1980. Charlotte Perkins Gilman: A feminist's struggle with womanhood. The Massachusetts Review 21: 503-526.

Johnston, G. 1991. Three men in Herland: Why they enter the text. Utopian Studies 4: 55-59.Kent, D. 2018. Early asexual feminists: The asexual history of social purity activists and spinsters. Making Queer History. https://www.makingqueerhistory.com/articles/2018/6/3/early-asexual-feminists-the-asexual-history-of-social-purity-activists-and-spinsters (23 October 2018).

Kessler, C. F. 1995. Daring to Dream: Utopian Fiction by United States Women before 1950. $2^{\text {nd }}$ ed. New York: Syracuse University Press.

Leslie, M. 1996. Gender, genre and the utopian body. Utopian Studies 7: 6-24.

Miller, M. 1983. The ideal woman in two feminist science-fiction utopias. Science Fiction Studies 10: 191-8.

Pearson, C. 1977. Women's fantasies and feminist utopias. Frontiers: A Journal of Women Studies 2: 50-61.

Pohl, N. 2003. Of mixt natures: Questions of genre in Margaret Cavendish's The Blazing World. In: S. Clucas (ed.), A Princely Brave Woman: Essays on Margaret Cavendish Duchess of Newcastle, 51-68. Aldershot: Ashgate.

Seago, K. 1999. New wine in old bottles?: Angela Carter's Bloody Chamber of revisioned fairy tales. Metaphore 26: 7-98.

Snodgrass, M. E. 2006. Encyclopedia of Feminist Literature. New York: Facts on File.

Trubowitz, R. 1992. The Reenchantment of utopia and the female monarchical self: Margaret Cavendish's blazing world. Tulsa Studies in Women's Literature 11: 229-245.

Warner, M. 2013. Melbourne writers festival. The Sunday Morning Herald. https: / / www.smh.com. au /entertainment/melbourne-writers-festival-20130815-2ryy๑.html (25 October 2018). West, L. 2015. Introduction in: Gilman, Charlotte Perkins (ed.), Herland, vii-xiii. London: Vintage Classics.

Winterson, J. 1995. Art and Lies. Canada: Vintage Books.

Woolf, V. 1996. A Room of One’s Own \& Three Guineas. Great Britain: Vintage.

\section{$* * *$}

Emma Crabtree is nearing the end of her MA at University of Buckingham by research which discusses Naomi Alderman's novel The Power and its presentation of the structures of power within society, in connection with fourth wave feminism. Women's writing is of key interest to her, 
especially female dystopian novels which are often driven by a critique of society through forceful feminist messages. 